\title{
Hepatitis B Virus (HBV) Variants in Hemodialysis Patients
}

\author{
Selma A. Gomes, Francisco C. Mello and Natalia M. Araujo \\ Laboratório de Virologia Molecular, \\ Instituto Oswaldo Cruz, FIOCRUZ, Rio de Janeiro, \\ RJ Brazil
}

\section{Introduction}

In this chapter we discuss the global epidemiology of hepatitis B virus (HBV) in the general population and compare the data with those from populations at higher risk for hepatitis $B$ infection, as hemodialysis patients. We discuss disease burden, HBV genotype distribution, and patterns of $\mathrm{HBV}$ transmission in the general population and among hemodialysis patients. We focus on the importance of detecting occult HBV infection in hemodialysis. Finally, we compare HBV variants detected in the general population with those detected by nosocomial transmission in hemodialysis units.

\section{History of hepatitis $B$ virus}

HBV is an etiologic agent of acute and chronic liver disease in humans. About one-third of people infected with HBV have a completely "silent" disease. When symptoms are present, they may be mild or severe. The most common early symptoms are mild fever, headache, muscle aches, fatigue, loss of appetite, nausea, vomiting and diarrhea. Later symptoms may include dark coffee-colored, rather than dark yellow, urine, clay-colored stools, abdominal pain, and yellowing of the skin and whites of the eyes (jaundice). Several reports of the occurrence of epidemic jaundice are found from the period before the Christian era, and were initially described by Hippocrates (400 BC). However, only in the late nineteenth century, after smallpox vaccination (vaccine prepared from human lymph) of 1,289 shipyard workers in Bremen, Germany, of which 15\% became jaundiced, it became clear the association of this illness with an agent of parenteral transmission (Lurman, 1885).

During the first half of the twentieth century, outbreaks of hepatitis of "long incubation period" (30-180 days) were observed in many countries and have been associated with blood transfusions, use of injectable drugs, unsterilized needles and syringes, and vaccine administration, for example, an outbreak of hepatitis/jaundice occurred in militaries who were vaccinated against yellow fever during the Second World War (Krugman, 1989).

The 1940s was the period in which distinguished the presence of more than one viral agent for the epidemic of jaundice. In 1947, MacCallum appointed the terms "hepatitis A virus" (HAV) and "hepatitis B virus" (HBV), referring to the presumed etiologic agents of hepatitis of short incubation period (18 to 37 days) and long incubation period (30 to 180 days), respectively. This terminology was adopted by the committee of viral hepatitis of the World Health Organization, staying until nowadays (Hollinger, 1991). 
In 1965, Blumberg and colleagues published what would become one of the most important revelations about viral hepatitis. With the aim of studying polymorphic hereditary characteristics, Blumberg and his team examined thousands of serum samples from different geographic areas of the world. During the course of the investigation, the team found that a serum sample from an Australian aborigine contained an antigen that reacted specifically with an antibody present in the serum of a hemophiliac patient in the United States. Subsequent studies revealed that this "Australia antigen" was relatively rare in the population of North America and Western Europe, but prevalent in some African and Asian regions and among patients with leukemia, Down syndrome and acute hepatitis (Bayer et al., 1968; Blumberg et al., 1967). In 1968, the correlation of the Australia antigen (now called the surface antigen of hepatitis $\mathrm{B}$ or HBsAg) with $\mathrm{HBV}$, could be established (Okochi\&Murakami, 1968; Prince, 1968). Subsequently, the purification of HBV was performed from serum of carriers of Australia antigen and the complete particle or virion was detected by electron microscopy (Dane et al., 1970).

\section{HBV routes of transmission}

HBV is present in high titers in blood and exudates of acutely and chronically infected persons. More moderate viral titers are found in semen, urine, saliva, and nasopharyngeal fluid (Alter et al., 1977; Davison et al., 1987). HBV is present in the blood of individuals positive for hepatitis B e antigen (HBeAg, a marker of high infectivity) at a concentration of approximately $10^{8}$ to $10^{9}$ viral particles per milliliter (mL) of blood (Dane et al., 1970). By comparison, human immunodeficiency virus (HIV) is present in blood at much lower concentrations: $10^{3}$ to $10^{4}$ viral particles/mL for a person with AIDS and 10 to $100 / \mathrm{mL}$ for a person with asymptomatic HIV infection (Ho et al., 1989). The risk of HBV transmission after percutaneous exposure to HBeAg-positive blood is approximately 100 -fold higher than the risk of HIV transmission after percutaneous exposure to HIV infected blood (CDC, 2011). In addition, HBV is an extremely resistant virus, capable of withstanding extreme temperature and humidity. $\mathrm{HBV}$ retains infectivity when stored at $30^{\circ} \mathrm{C}$ to $32^{\circ} \mathrm{C}$ for at least 6 months and when frozen at $-15^{\circ} \mathrm{C}$ for 15 years. HBV present in blood can resist drying on a surface for at least a week (Hollinger\&Liang, 2001). These characteristics explain why HBV is so highly transmissible by a variety of percutaneous procedures, with an annual global estimation of 8-16 million new HBV infections due to the use of unsafe injections (Simonsen et al., 1999).

HBV transmission occurs mainly by percutaneous or mucosal exposure to infected blood. It also occurs through perinatal exposure, sexual intercourse, exposure to blood products (needles shared by intravenous drug users, by skin lesions) and through organ transplantation. In areas of high incidence of HBV infection, dissemination occurs mainly in children, either at birth (perinatal) or during the first years of life by horizontal transmission among family members (Margolis et al., 1991). Perinatal transmission from mother to child may occur during birth by newborn exposure to blood or amniotic fluid. In areas of low prevalence, the infection occurs primarily in adults. Individuals at high risk for HBV infection are injecting drug users (Alter, 1993; Oliveira et al., 1999), homosexual or heterosexual individuals with multiple sexual partners (Piot et al., 1990), health professionals (Beltrami et al., 2000) and polytransfused patients. Patients undergoing hemodialysis are at high risk of acquiring HBV (Canero-Velasco et al., 1998; Covic et al., 1999; Vladutiu et al., 2000). 


\section{Clinical features}

It is believed that the HBV itself does not exert a direct cytopathic effect on hepatocytes (Alberti et al., 1983). Hepatitis B infection can, however, vary from an acute self-limited to a severe form of fulminant hepatitis. The course of HBV infection can be extremely variable. It may be unapparent or patients may develop symptoms. Asymptomatic cases can be identified by detecting biochemical or virus specific serological alterations. Symptoms range from mild to severe. It is estimated that about $90-95 \%$ of infected adults will recover from the infection, and less than $1 \%$ of individuals may develop a fulminant hepatitis. However, children up to 5 years old, have over $90 \%$ of chance of becoming chronic carriers due to the immature immune system. Patients with acute hepatitis may recover completely or progress to chronic hepatitis. Acute hepatitis can be divided into four clinical phases (a) incubation period that usually ranges from 30 to 180 days; (b) pre-icteric phase, ranging from several days to more than a week. This phase is typically characterized by mild fever, fatigability, anorexia, nausea and vomiting. At this stage, patients may refer diffuse abdominal pain, intolerance to various foods, taste disturbances, abdominal discomfort. The occurrence of arthritis, arthralgia and myalgia are described as well as the observation rubelliform rashes (McIntyre, 1990). Physical examination may reveal a mild hepatomegaly; (c) icteric phase that is characterized by the appearance of dark, golden-brown urine, followed by pale stools and discoloration of the mucous membranes, conjunctivae, and skin. This icteric phase begins within 10 days of the initial symptoms in over $85 \%$ of the HBV cases and; (d) convalescent period. In this stage, with the evolution of the disease, painful hepatomegaly and splenomegaly, and any gastrointestinal symptoms and those related to jaundice, if present, will gradually diminish. This recovery period lasts on average 20 to 30 days.

\section{HBV open reading frames}

HBV represents the prototype of Hepadnaviridae family (genus Orthohepadnavirus) where a group of singular few viruses with genomes composed by a partial double stranded DNA replicating via reverse transcriptase were clustered. HBV is one of the smallest genomes of human viruses, with about $3.2 \mathrm{~Kb}$. The HBV genome is fully coding with four open reading frames designated pre-S/S, pre-C/C, P and X. All the virus genes are overlapped at least to one other open reading frame, and due to this characteristic, HBV may produce about $50 \%$ more proteins than expected for the size of its genome (Ganem\&Varmus, 1987). The genomic pre-S/S region encodes the viral surface proteins (HBsAg) that is abundant in serum of infected individual. The pre-C/C region is responsible for the synthesis of the proteins that form HBV capsid, named core antigen (HBcAg). This region also synthesizes the e antigen (HBeAg) that is secreted from HBV particles and is found free in the serum of infected individuals. HBeAg is an important marker of active replication. The open reading frame for the polymerase ( $\mathrm{P}$ gene) encodes the viral polymerase with activity of reverse transcriptase, and RNAseH. This protein is the target of anti-HBV drugs (see Topic 9). A small gene named $X$ synthesizes a regulatory protein, called protein $X(\mathrm{HBxAg})$. Almost all $\mathrm{HBV}$ proteins and antibodies against these products are important markers for $\mathrm{HBV}$ serological detection.

\section{HBV serological and molecular markers of infection}

From a clinical point of view, viral hepatitis has very similar symptoms. The etiological diagnosis to identify the causative agent of infection can be performed by serological 
techniques, immuno-histochemical and molecular research. Biochemical tests of liver function, such as determination of transaminases (alanine aminotransferase - ALT and aspartate aminotransferase - AST) and bilirubin are also performed for diagnostic purposes, because their serum levels increase during episodes of hepatocellular injury or necrosis due to viral infection (Sjogren, 1994). The symptoms start with the elevation of aminotransferases, and patients become positive to anti-HBc IgM. Anti-HBc IgM together with $\mathrm{HBsAg}$, is the key to diagnosing acute infection, since the IgG fraction of this antibody serves only as evidence of immune memory. Despite being a long-lasting antibody, anti-HBc does not confer immunity to the individual, it does not have neutralizing capacity (Sjogren, 1994). The early disease markers of virus replication (HBeAg and HBV-DNA) are found in high titers. As the infection sets in, the host immune response modulates the infection and progressively decreases viral replication. Individuals who present satisfactory immune response can resolve viral replication, usually within the first 3 months of illness, giving rise to anti-HBe antibody, which is associated with a poor replication of HBV. The absence of the seroconversion $\mathrm{HBeAg} /$ anti-HBe within the first 3 months of acute illness is a sign of poor prognosis, indicating failure of the immune system and tendency to chronicity of the process. Upon the termination of viral replication, HBsAg gradually disappears and, after a few weeks, anti-HBs emerges, thus, conferring immunity to the patient. Chronic hepatitis is determined by the persistence of HBsAg in serum for more than six months after the onset of infection. In chronic patients, markers of viral replication and clinical manifestations are dependent on the virus-host interactions (Sjogren, 1994).

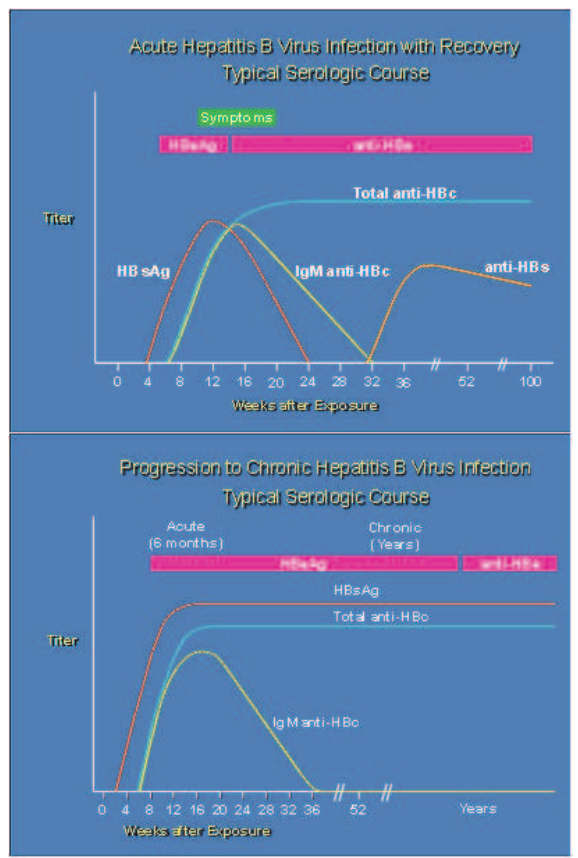

Fig. 1. Typical serologic course of acute and chronic HBV infections. Available in <http://www.cdc.gov/ncidod/diseases/hepatitis/slideset/hep_b/slide_3.htm> and <http://www.cdc.gov / ncidod/diseases/hepatitis/slideset/hep_b/slide_4.htm> [Accessed on 16 Jan. 2008]. 
Figure 1 shows the curves of serological markers in acute and chronic HBV infections. Table 1 provides interpretations for hepatitis B serologic markers.

\begin{tabular}{|c|c|c|}
\hline $\begin{array}{l}\text { HBsAg } \\
\text { anti-HBc } \\
\text { anti-HBs }\end{array}$ & $\begin{array}{l}\text { negative } \\
\text { negative } \\
\text { negative }\end{array}$ & Susceptible \\
\hline $\begin{array}{l}\text { HBsAg } \\
\text { anti-HBc } \\
\text { anti-HBs }\end{array}$ & $\begin{array}{l}\text { negative } \\
\text { positive } \\
\text { positive }\end{array}$ & Immune due to natural infection \\
\hline $\begin{array}{l}\text { HBsAg } \\
\text { anti-HBc } \\
\text { anti-HBs }\end{array}$ & $\begin{array}{l}\text { negative } \\
\text { negative } \\
\text { positive }\end{array}$ & Immune due to hepatitis B vaccination \\
\hline $\begin{array}{l}\text { HBsAg } \\
\text { anti-HBc } \\
\text { IgM anti-HBc } \\
\text { anti-HBs }\end{array}$ & $\begin{array}{l}\text { positive } \\
\text { positive } \\
\text { positive } \\
\text { negative }\end{array}$ & Acutely infected \\
\hline $\begin{array}{l}\mathrm{HBsAg} \\
\text { anti-HBc } \\
\text { IgM anti-HBc } \\
\text { anti-HBs }\end{array}$ & $\begin{array}{l}\text { positive } \\
\text { positive } \\
\text { negative } \\
\text { negative }\end{array}$ & Chronically infected \\
\hline $\begin{array}{l}\text { HBsAg } \\
\text { anti-HBc } \\
\text { anti-HBs }\end{array}$ & $\begin{array}{l}\text { negative } \\
\text { positive } \\
\text { negative }\end{array}$ & $\begin{array}{l}\text { Interpretation unclear; four possibilities: } \\
\text { 1. Resolved infection (most common) } \\
\text { 2. False-positive anti-HBc, thus susceptible } \\
\text { 3. "Low level" chronic infection } \\
\text { 4. Resolving acute infection }\end{array}$ \\
\hline
\end{tabular}

Table 1. Interpretation of hepatitis B serologic test results. Available in <http://www.cdc.gov/hepatitis/HBV/PDFs/SerologicChartv8.pdf> [Accessed on 01 April 2011].

\section{Epidemiology of HBV}

According to the most recent data of World Health Organization (WHO, 2008), it is estimated that more than 2 billion people worldwide have been infected with HBV. Of these, approximately 360 million suffer from chronic HBV infection, resulting in over 
600.000 deaths each year mainly from cirrhosis or liver cancer. The distribution of HBV infection is not uniform around the world. The world areas were classified into high, medium or low endemicity for HBV, depending on the prevalence of the HBV serological marker of active infection, the HBsAg. HBsAg is highly prevalent (8-15\%) in Southeast Asia, China, Philippines, Africa, the Amazon basin and the Middle East. An intermediate prevalence of HBsAg (2-7\%) is observed in Eastern Europe, Central Asia, Japan, Israel and Russia, while a low prevalence $(<2 \%)$ is found in North America, Western Europe, Australia and South America (CDC, 2011) (Figure 2). About 45\% of HBV infected people are living in areas where HBsAg prevalence is $8 \%$ or higher, with a risk of infection of more than $60 \%$, mostly during the childhood and with a high risk of chronicity. Forty-three percent of worldwide infected people are living in areas of intermediate prevalence with risk of infection of $20-60 \%$, occurring across all age groups. Only the remaining $12 \%$ are living in areas of low prevalence with risk of infection of less than $20 \%$, occurring mainly in adulthood (Te\&Jensen, 2010). Despite the impressive number of HBV infected people, the worldwide incidence is in decreasing mostly due to the effort toward global prevention of hepatitis B by vaccination. Hepatitis B vaccine has been available since 1982 and at least 1 billion people have been vaccinated worldwide. The efficacy of HBV vaccination in the prevention of HBV infection has been shown to be over $90 \%$ in most countries (de Franchis et al., 2003) and universal vaccination is regarded to be the key toward elimination and eradication of HBV (Chen, 2009).

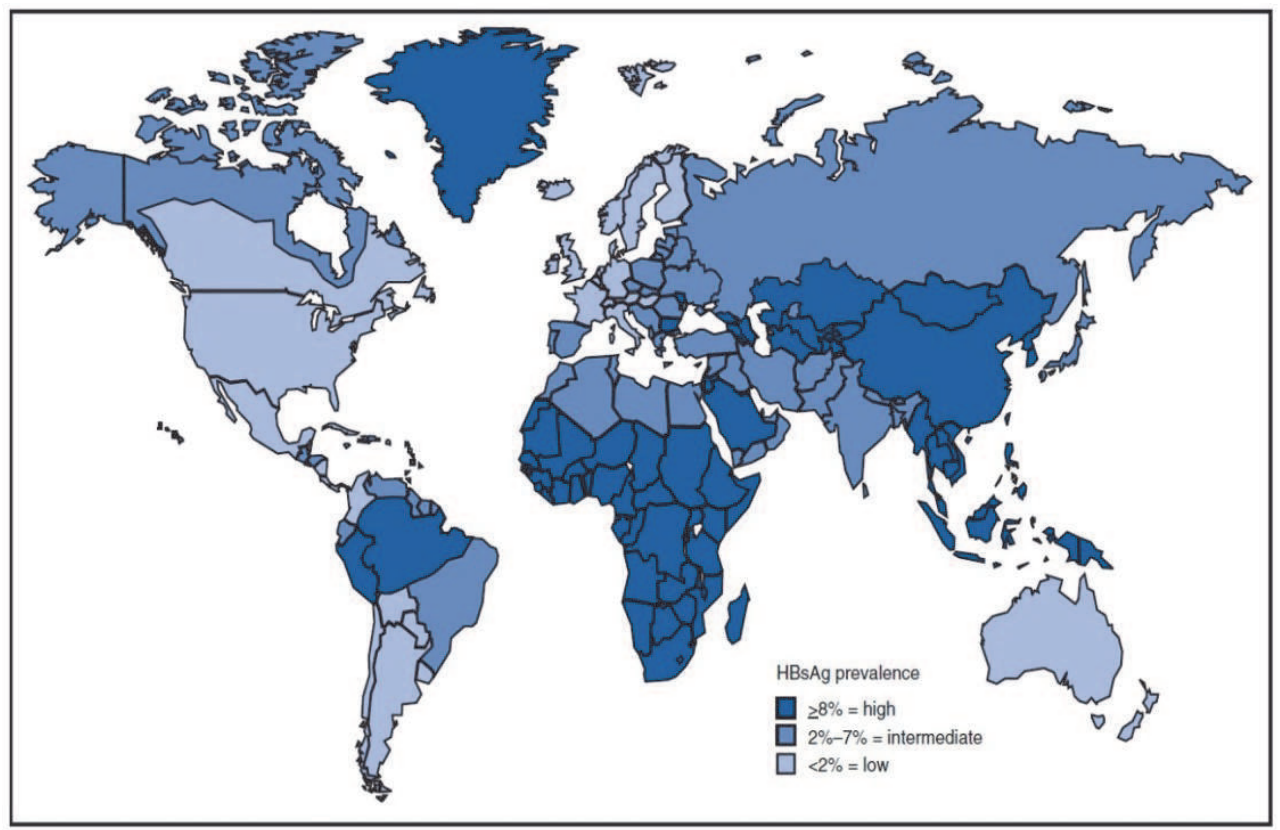

Fig. 2. Geographic distributions of hepatitis B infection worldwide, 2006. (Data from Central Disease Control, available from:

http://www.cdc.gov/hepatitis/HBV/PDFs/HBV_figure3map_08-27-08.pdf 


\section{Prevention of hepatitis $B$}

The first HBV vaccine was licensed in 1981 and was derived from human plasma of chronic HBV (Heptavax-B, Merck \& Co). However, the risk of transmission of other infectious agents present in the plasma, has stimulated the development of recombinant vaccines composed of HBsAg produced by genetic engineering (Engerix-B, Recombivax and SmithKline, Merck \& Co). For the production of vaccines, recombinant DNA technology uses expression of HBsAg in yeast (Assad\&Francis, 1999). The vaccine has good immunogenicity against $\mathrm{HBV}$, approximately $90 \%$ of immunocompetent individuals vaccinated develop an adequate antibody response. Moreover, the vaccine has the potential to reduce the incidence of liver cancer (Blumberg, 1997). The scheme currently recommended to the recombinant vaccines is 3 doses intramuscularly in the deltoid muscle at intervals of one month (between 1st and 2nd dose) and 5 months (between 2nd and 3rd dose) - Schema 0, 1, 6 months (Assad\&Francis, 1999). The protective efficacy of HBV vaccine is directly related to the level of anti-HBs produced and it is necessary for protection levels equal or greater than $10 \mathrm{mIU} / \mathrm{ml}$ (CDC, 1991). The immunoprophylaxis through the use of specific hyperimmune globulin (HBIG) is used to give immediate passive protection to individuals who have been recently exposed to $\mathrm{HBV}$, for example, after an accidental puncture, sexual contact with a carrier or, during delivery of newborns of HBsAg positive mothers (Perrillo et al., 1984).

\section{Treatment of chronic hepatitis B infection}

The main goal of treatment for chronic hepatitis B is to suppress viral replication and reducing liver damage, preventing the progression to cirrhosis and hepatocellular carcinoma. Parameters of response to treatment to be considered are: 1) seroconversion of HBeAg to anti-HBe, 2) disappearance of HBV DNA from serum, 3) normalization of ALT level, and 4) improvement of liver histology. Two therapeutic approaches have been used in the treatment of HBV chronic infections: immune modulators and antiviral agents in the form of analogues of nucleos(t)ides. In the first category, conventional or pegylated interferon alpha (IFN- $\alpha$ ) is the unique option. Approximately 20\% of $\mathrm{HBeAg}$ positive patients treated with IFN seroconverted to anti-HBe (Karayiannis, 2004). Treatment with IFN has advantages such as a short duration (six months to one year) of treatment, absence of antiviral resistance and excellent quality and duration of response. Its disadvantages are mainly the side effects such as flu-like symptoms and hematologic, neuropsychiatric, dermatological, endocrine, respiratory, ophthalmic and cardiovascular reactions (Fattovich et al., 1996). The second class of antiviral agents for the treatment of chronic hepatitis B is the analogs of nucleos(t)ides. Today five drugs, lamivudine, adefovir dipivoxil, entecavir, telbivudine, and tenofovir have been approved in many parts of the world (Dienstag, 2008). These agents inhibit reverse transcription of the HBV polymerase and are well tolerated. However the occurrence of drug resistant viral isolates has been the main factor limiting the effectiveness of these drugs. These analogs of nucleos(t)ides are also used as part of the highly active antiretroviral therapy to treat HIV infection. HBV clinical trials and concurrent improvements in diagnostic technology may ensure that treatment options and expert opinion on patient management will continue to evolve. HBV genotyping and phenotyping of resistant isolates helps to delineate patterns of resistance and cross-resistance. These data may help to maximize the benefits of antiviral agents and improve the design of new therapeutic strategies (Zoulim\&Locarnini, 2009). 


\section{Geographic distribution of HBV genotypes in the general population}

HBV is a unique enveloped double-stranded DNA virus that employs the error-prone polymerase reverse transcriptase as part of its replication process. This has resulted in a large genetic variability over the years of virus evolution within its hosts. Based on sequence divergence in the entire genome of $8 \%$ or more, $\mathrm{HBV}$ isolates are classified into eight genotypes, designated $\mathrm{A}$ to $\mathrm{H}$, with a distinct geographical distribution (Arauz-Ruiz et al., 2002; Norder et al., 2004; Norder et al., 1994; Stuyver et al., 2000). Genotype A circulates in Europe, India, Africa, and North and South Americas. Isolates belonging to genotypes B and $C$ have been observed in Southeast Asia and the Far East. Genotype D is widespread, with a high prevalence in the Mediterranean area and in the Middle East region. Genotype $G$ is infrequent and has mainly been found in Europe, Mexico, and USA, while genotype $\mathrm{E}$ is native from West Africa and genotypes $\mathrm{F}$ and $\mathrm{H}$ are considered indigenous to Latin America (Figure 3). Recently, two novel genotypes, I and J, the former described in Laos and Vietnam (Olinger et al., 2008; Tran et al., 2008), and the latter in Japan (Tatematsu et al., 2009), have been proposed, but their designation as new genotypes is still controversial. There is a great deal of diversity within the genotypes and this has led to the division of some genotypes into different subgenotypes, such as $\mathrm{A} 1-\mathrm{A} 6$ in $\mathrm{HBV}$ of genotype $\mathrm{A}(\mathrm{HBV} / \mathrm{A}), \mathrm{B} 1-\mathrm{B} 8$ in $\mathrm{HBV} / \mathrm{B}, \mathrm{C} 1-\mathrm{C} 10$ in $\mathrm{HBV} / \mathrm{C}$, D1-D7 in HBV/D, and F1-F4 in HBV/F (Huy et al., 2006; Kramvis et al., 2008; Lusida et al., 2008; Meldal et al., 2009; Mulyanto et al., 2009; Norder et al., 2004; Nurainy et al., 2008; Pourkarim et al., 2010; Sakamoto et al., 2006; Utsumi et al., 2009; Wang et al., 2007).

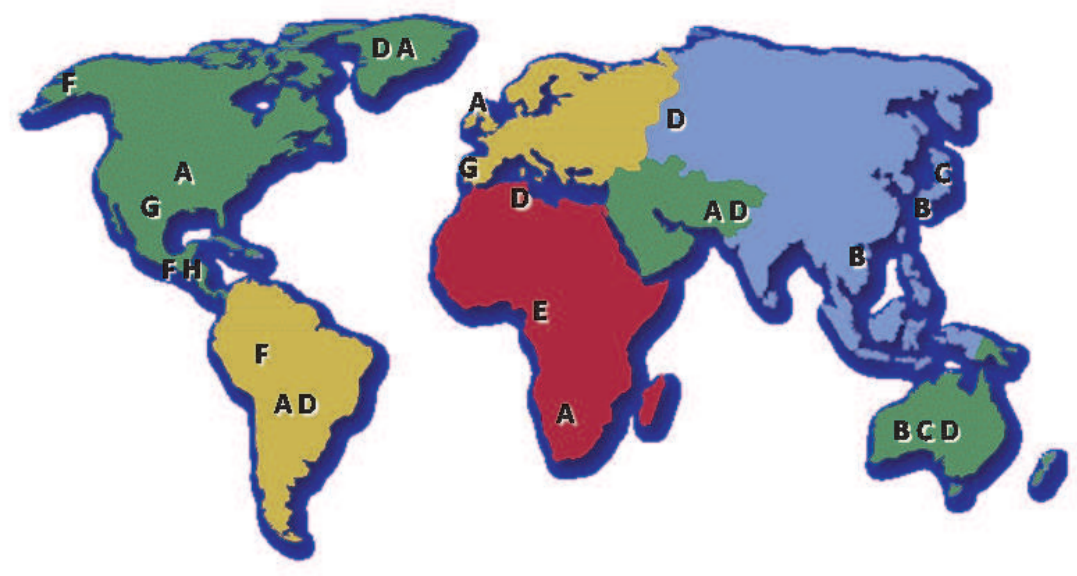

Fig. 3. Worldwide distribution of HBV genotypes. Adapted from <http://web.ucsf.edu/sfhbc/elective/2005/fall/Virology_Bass.ppt> [Date of access: 21 June 2008]. 


\section{HBV and hemodialysis}

It is well known that hemodialysis patients are at high risk of acquiring parenterally transmitted infections, not only because of the large number of blood transfusions that they receive, and the invasive procedures that they undergo, but also because of their immunosuppressed state. The prevalence of HBV infection in patients on maintenance hemodialysis is usually higher compared with rates from the general population. Recent data from Mexico showed that prevalence of HBV infection in patients on maintenance hemodialysis was about 7\%, 35 times higher than in the general population (Paniagua et al., 2010). In dialysis units both patient-to-patient and patient-to-staff transmission of HBV have been recognized since the 1960s. Controlling the spread of HBV infection in dialysis units has been a major advance in the management of patients with chronic kidney diseases. Before the advent of vaccination, some success in limiting the spread of HBV was achieved by dialysing seropositive patients separately from those who were seronegative. This followed the publication in the UK of the Rosenheim Report in 1972 (RosenheimAdvisoryGroup, 1972), which set out a code of practice for reducing transmission of hepatitis among dialysis patients. Before adoption of the universal infection control practices and HBV vaccination, high prevalence rates of HBV serological markers were found in hemodialysis patients globally. In addition to epidemiologic issues, management of HBV infection in dialysis population has evolved because of advances in antiviral therapy and improvements in diagnostic techniques (Fabrizi et al., 2008).

The rate of de novo HBV infection in patients undergoing regular hemodialysis in the developed world is currently low (Finelli et al., 2005). In developed countries, where the infection control procedures have been implemented, HBV infection declined significantly, reaching HBsAg rates lower than 1.0\% (Alter et al., 1986; Tokars et al., 2002). However, outbreaks of HBV infection continue to be reported occasionally in dialysis units in the developed world with some cases of fulminating hepatitis and even death (Inoue et al., 2006; Kondili et al., 2006). In the less-developed world, where the hemodialysis infection control practices and hepatitis B vaccination have been implemented lately, there are reports with rates of chronic HBsAg carriers ranging between 2\% and 20\% (Boulaajaj et al., 2005; Busek et al., 2002; Chattopadhyay et al., 2005; Covic et al., 1999; Fabrizi et al., 2008; Teles et al., 2002; Vladutiu et al., 2000). The higher HBV infection rates within dialysis units in the developing world can be attributed to several factors, an important one being the higher background prevalence of $\mathrm{HBV}$ in the general population. Also playing a prominent role are difficulties following infection control strategies against $\mathrm{HBV}$ such as, routine hemodialysis precautions, separating HBsAg-positive patients by rooms, machines, and staff, vaccination against $\mathrm{HBV}$, and blood screening, attributable, at least in part, to a lack of financial and other resources (CDC, 2001).

\section{Occult HBV infection in hemodialysis patients}

HBsAg is the established serological marker for the diagnosis of acute or chronic HBV infection, and the absence of HBsAg in serum has been used as a surrogate marker for the absence of DNA and active viral replication. However, the development of highly sensitive molecular biology techniques has allowed detection of low levels of HBV DNA in the serum and/or liver of patients without detectable HBsAg (Coursaget et al., 1991; Gomes et al., 1996; Hu, 2002; Jeantet et al., 2002). This peculiar form of chronic viral infection has been 
termed occult HBV infection (Hu, 2002; Raimondo et al., 2007; Torbenson\&Thomas, 2002). Individuals with occult HBV infection usually have serological evidence of previous exposure to the virus, mainly antibodies to core antigen (anti-HBc), although the absence of any serological marker related to HBV has also been described (Villa et al., 1995). Several possible explanations for HBV DNA persistence in the absence of HBsAg have been proposed. Low rate of HBV replication due to host's immune response or co-infection with other infectious agents may account for occult status in the majority of the cases (Raimondo et al., 2007). However, occult HBV infection may also be due to mutations that inhibit HBsAg expression (Chaudhuri et al., 2004) or change HBsAg antigenicity, thus preventing detection by commercial assays (Araujo et al., 2008; Carman et al., 1997; Jeantet et al., 2004; Yamamoto et al., 1994).

The prevalence of occult HBV infection is variable in different populations and depends on the general prevalence of HBV (Allain, 2004; Hu, 2002). The apparent prevalence also depends on the relative sensitivity of HBsAg and HBV DNA assays (Brechot et al., 2001; Conjeevaram\&Lok, 2001). Occult HBV infection has been documented in a variety of clinical situations, most commonly among patients with hepatitis $\mathrm{C}$ virus (HCV) infection, in which the highest prevalence of occult HBV has been observed, especially in those who are positive for anti-HBc (Chemin\&Trepo, 2005; Torbenson\&Thomas, 2002). It is now established that occult HBV infection among non-HCV patients suffering from chronic hepatitis ranges from $20-30 \%$ in Europe and, in the context of HCV infection, ranges from $20 \%$ in France to $80 \%$ in Japan (Chemin\&Trepo, 2005). Individuals at high risk of parenterally transmitted infections also have a high prevalence of occult HBV infection. Therefore, hemodialysis patients are at increased risk of occult HBV infection. Parenteral exposure also favors contamination by HCV (Dai et al., 2001).

The studies performed up to now on hemodialysis patients provide widely divergent results, reporting a prevalence of occult HBV that ranges from $0 \%$ to 36\% (Besisik et al., 2003; Fabrizi et al., 2005; Goral et al., 2006; Kanbay et al., 2006; Minuk et al., 2004; Motta et al., 2010; Siagris et al., 2006). These apparent discrepancies may be explained by significant differences in the prevalence of HBV infection in different geographic regions and/or by the detection limits of different HBV-DNA assays. In this context, it is of note that several authors consider occult HBV as a possible source of virus spread in hemodialysis units, thus representing a risk of infection for both patients and staff, and suggest some precautions including HBV DNA screening for all hemodialysis patients (Minuk et al., 2004).

\section{HBV variants in the general population vs. among hemodialysis patients}

In this topic, we will discuss the flow of contamination of different HBV genotypes in hemodialysis centers. We will address the circulation of $\mathrm{HBV}$ variants in the general population and among hemodialysis patients. Are some genotypes more disseminated in the hemodialysis environment? How to trace nosocomial transmission?

HBV itself is not a directly cytotoxic virus. Instead, it destroys liver cells indirectly by stimulating the immune response. When the body fails to produce a sufficiently vigorous immune response to $\mathrm{HBV}$ during initial infection, chronic infection develops. This persistent but ineffective response results in progressive liver damage and fibrosis (Lindh et al., 1999). Although the host's immune response to HBV infection determines the extent of liver injury, evidence of an association between HBV genotypes and clinical outcomes, activity of liver disease, HBV replication, and treatment responses, is growing (Chu\&Lok, 2002; Kao, 2002; 
Mayerat et al., 1999; McMahon, 2009; Schaefer, 2005). An association between genotype A and a chronic outcome of HBV infection has been proposed (Mayerat et al., 1999; Ozasa et al., 2006). It has been demonstrated that the replication capacity of HBV in transfected hepatoma cells varied among HBV genotypes, with genotype A having the lowest replication capacity (Sugiyama et al., 2006). Therefore, it is probable that the propensity of HBV genotype A infections to lead to chronicity would be due to less intensive immune responses because of its slow viral dynamics (Ozasa et al., 2006). In addition, the analysis of the level of cellular stress induced by transfection with distinct HBV genotypes revealed that the lowest level was achieved with genotype A (Sugiyama et al., 2006). On the other hand, the majority of cross-sectional and prospective studies show that individuals infected with HBV genotype $C$ have an increased and earlier risk of liver inflammation, liver fibrosis, cirrhosis and liver cancer than those infected with other genotypes, including genotype $\mathrm{B}$ that co-exists in the same geographic area, suggesting that genotype $\mathrm{C}$ may be the most virulent of the HBV genotypes (Chan et al., 2004; Chen et al., 2004; Kao, 2002). People infected with HBV genotype C clearly have higher levels of HBV DNA, as evidenced by prolonged HBeAg positivity, than those infected with other genotypes. As a result, they experience prolonged viremia throughout much of their lives, giving more time for HBV integration to occur and more opportunity for liver inflammation and fibrosis. Additionally, certain mutations such as the basal core promoter mutation, that independently may be associated with a higher risk of liver cancer, appear to occur more frequently in those infected with genotype C (McMahon, 2009).

Antiviral resistance to nucleos(t)ides analogs used for hepatitis $\mathrm{B}$ treatment has been associated with the genetic variability of HBV (Kramvis\&Kew, 2005; Liu\&Kao, 2008; Wiegand et al., 2008). Among the five nucleos(t)ides analogs licensed for treatment (see Topic 9), primary resistance mutations have been identified for lamivudine (Allen et al., 1998), telbivudine (Yang et al., 2005), entecavir (Colonno et al., 2006) and adefovir (Angus et al., 2003). Only tenofovir is not certain to cause resistance. All drug resistant mutations are confined to eight $(169,180,181,184,202,204,236$ and 250) aminoacid positions of the reverse transcriptase domain of pol gene (Locarnini, 2008). Lamivudine, also known as 3TC, was the first nucleoside analog to be licensed by the FDA for use in the treatment of chronic HBV infection in 1998 (Karayiannis, 2004). Primary lamivudine resistance associated changes result in amino acid changes within the tyrosine-methionine-aspartate-aspartate (YMDD) motif - rtM204V/I (methionine to valine or isoleucine substitution at codon 204). These changes cause a greater than 100 -fold decrease in susceptibility to lamivudine in phenotypic assays. The compensatory mutations associated with lamivudine resistance, rtV173L (valine to leucine substitution), and rtL180M (leucine to methionine substitution) restore replication fitness of $\mathrm{HBV}$ polymerase that harbors the $\mathrm{rtM} 204 \mathrm{~V} / \mathrm{I}$ mutation (Ono et al., 2001).

The genetic variability of HBV strains circulating in hemodialysis units has been an important matter of study worldwide. One of the most extensive studies of HBV contamination and nonequivalent, genotype-specific spread in hemodialysis centers was conducted in Goiania city, located at the Central-West region of Brazil (Teles et al., 2002). Brazil, a country with a highly miscegenated population, exhibits an HBV genotype circulation pattern that is distinct from the distribution found in other Latin American countries. In Brazil, genotypes A, D and F co-circulate. Of these, subgenotype A1, the African subgenotype of genotype A (Bowyer et al., 1997; Kramvis et al., 2002), is the most prevalent among Brazilian HBV carriers (Araujo et al., 2004; Mello et al., 2007). The 
distribution of HBV genotypes A and D in Brazil exhibit a gradient from northern to southern regions, reflecting the influence of Caucasian, African, and native Indian populations. North, Northeast and Southeast regions show a higher prevalence of genotype A. The high rate of genotype D isolates in the South region could be related to the influx of immigrants from Central Europe (especially Germany and Italy) that occurred in that region at the beginning of the $20^{\text {th }}$ century. The balanced distribution of genotypes A and D in the Central-West region could be explained by the delayed occupation of that area by population migration flows from South, Southeast and Northeast regions (Mello et al., 2007). According to the study of Teles and cols. (Teles et al., 2002), in 1995, HBsAg prevalence among hemodialysis patients was approximately $10 \%$, and genotypes A (50\%) and D $(46.2 \%)$ were almost detected equally in hemodialysis units from Goiania city. A survey of hemodialysis units in this city from 1995 to 1999 indicated that all newly infected patients harbored genotype D. By 1999, this resulted in a shift to genotype D being the predominant genotype (65.5\%) (Teles et al., 2002). These data suggest that genotype D would be more likely to disseminate in the hemodialysis environment. In fact, although genotype $\mathrm{A}$ is the most prevalent genotype in Brazil, HBV genotype D strains have been involved frequently in hepatitis B outbreaks in dialysis units (Castro-Figueiredo et al., 1986; De Castro et al., 2000; Lewis-Ximenez et al., 2001; Roll et al., 1995), and in some of these cases they were probably more efficiently transmitted than genotype A (Castro-Figueiredo et al., 1986; De Castro et al., 2000; Teles et al., 2002). Additionally, several studies have shown a significant association of HBV genotype D and injection drug use (Fisker et al., 2004; Panessa et al., 2009; Swenson et al., 2001), reinforcing the idea that genotype D could be a blood-borne genotype. Other studies focusing on the molecular analysis of HBV isolates have been reported a high prevalence of genotype $\mathrm{H}$ and genotype $\mathrm{B}$ among hemodialysis patients from Mexico (Alvarado-Esquivel et al., 2006) and Indonesia (Lusida et al., 2003), respectively.

Nosocomial transmission in the dialysis setting has been reported as a result of reusing multi-dose vials, staff shortages and subsequent need to care simultaneously for HBV infected and uninfected individuals, and contamination of equipment and environmental surfaces (Wreghitt, 1999). To confirm a common source of infection, it is necessary to demonstrate that patients have been infected with the same strain of virus. A nosocomial transmission of hepatitis B genotype E in UK has been recently reported (Ramalingam et al., 2007). In this study, it was likely that two independent transmission events occurred in the ward and/or in the theatre recovery area. Both patients 1 and 2 with acute hepatitis B, and patient 3, an anti-HBe positive carrier had genotype E infections. The phylogenetic analyses demonstrated that the HBV strain infecting the three patients were identical in both the surface and core regions (Ramalingam et al., 2007). De Castro and cols. investigated the genetic variability of HBV strains circulating in two hemodialysis units by RFLP analysis (De Castro et al., 2000). Comparison between RFLP patterns of HBV strains was thus used to assess the nosocomial spread of HBV infection in each hemodialysis center. In this study, viral isolates of $27 \mathrm{HBsAg}$ positive hemodialysis patients and $39 \mathrm{HBV}$-positive unrelated control patients, were grouped according to their RFLP patterns. In hemodialysis unit A, 14 $\mathrm{HBV}$ isolates were grouped into five different RFLP patterns: A1, A2 and A3 (for genotype A strains), and, D3 and D4 (for genotype D). Pattern A2, present at a relatively low prevalence $(18 \%)$ in the control group, was observed in the majority $(53 \%)$ of the hemodialysis patients. Notably, all five patients who seroconverted to HBsAg positivity in 1995 carried the strain of RFLP pattern A2. In hemodialysis unit B, where an outbreak of 
HBV infection occurred in 1996-1997, RFLP analysis showed that all 13 patients who seroconverted to HBsAg were infected with HBV isolates of genotype D. Coinfection with strains of RFLP pattern A1 was detected in seven of them (De Castro et al., 2000).

There are concerns about HBV variants detected in cases of occult infection, if they may be transmitted to other hemodialysis patients and whether or not they may cause liver disease. Interesting, two studies, one performed in Turkey (Besisik et al., 2003) and other in Brazil (Motta et al., 2010), reported high prevalence of lamivudine resistant mutations in a significant proportion of hemodialysis patients with occult HBV infection, who had not previously received lamivudine treatment. It has been demonstrated that $\mathrm{rtM} 204 \mathrm{~V} / \mathrm{I}$ mutants have a markedly decreased replication phenotype compared with wild-type HBV (Melegari et al., 1998), whereas both rtV173L and rtL180M substitutions act as compensatory changes that partially restore the replication fitness of the virus (Delaney et al., 2003; Ono et al., 2001). The triple lamivudine resistance mutation causes the concomitant amino acid substitutions E164D and I195M in the HBsAg as a result of the overlapping reading frames of the envelope and polymerase genes (Locarnini, 1998). It has been shown that both E164D and I195M substitutions reduce in vitro affinity of HBsAg to anti-HBs antibodies, similar to the HBV vaccine escape mutant G145R (Torresi et al., 2002). The HBsAg Y100C substitution is also frequently found among occult HBV infection carriers. Y100C has been found in cases of occult HBV infection among Venezuelan blood donors (Gutierrez et al., 2004), individuals from an Afro-Brazilian community (Motta-Castro et al., 2008) and HIV-HBV co-infected patients (Araujo et al., 2008). Among hemodialysis patients with occult HBV infection, the Y100C mutation has been also frequently found (Motta et al., 2010). Due to these observations, the role of Y100C substitution in reducing

amount of HBsAg or changing HBsAg affinity by commercial antibodies was recently investigated by Mello and cols. (Mello et al., 2011). This study compared the levels of HBsAg detected by ELISA after transfection assays using recombinant plasmids with or without Y100C substitution. The results indicated that Y100C substitution alone did not negatively affect the detection and/or secretion of HBsAg. However, further studies analyzing the complete genome of HBV strains with the Y100C substitution may elucidate whether this mutation affects $\mathrm{HBV}$ replication or if there are mutations in other $\mathrm{HBV}$ genomic region that could explain the association of these variants with occult hepatitis B infection (Mello et al., 2011).

\section{Conclusions}

Hepatitis B remains a major health issue in dialysis patients. Despite the introduction of effective infection control measures to minimize patient-to-patient transmission, occasional outbreaks occur in dialysis units, usually because of lapses in practice. Although the importance of occult HBV infection in the pathogenesis of hepatic disease has not yet been established, an increase number of studies have indicated a need to survey this group of patients. Occult HBV infection has been frequently observed among hemodialysis patients and could be a source of viral spread within hemodialysis units, representing a risk of infection for both patients and staff. YMDD variants are a common accompaniment and require further investigations with regard to clinical implications, once lamivudine treatment of possible HBV relapse in these patients might be accompanied by fast-viral resistance formation. Therefore, further studies with genome sequencing may provide more detail information on the molecular epidemiology of HBV infection, which may be helpful in understanding the HBV transmission in the hemodialysis population. 


\section{References}

Alberti, A., F. Tremolada, G. Fattovich, F. Bortolotti, and G. Realdi. (1983). Virus replication and liver disease in chronic hepatitis B virus infection. Dig Dis Sci, 28 (11):961-966.

Allain, J. P. (2004). Occult hepatitis B virus infection. Transfus Clin Biol, 11 (1):18-25.

Allen, M. I., M. Deslauriers, C. W. Andrews, G. A. Tipples, K. A. Walters, D. L. Tyrrell, N. Brown, and L. D. Condreay. (1998). Identification and characterization of mutations in hepatitis B virus resistant to lamivudine. Lamivudine Clinical Investigation Group. Hepatology, 27 (6):1670-1677.

Alter, H. J., R. H. Purcell, J. L. Gerin, W. T. London, P. M. Kaplan, V. J. McAuliffe, J. Wagner, and P. V. Holland. (1977). Transmission of hepatitis B to chimpanzees by hepatitis B surface antigen-positive saliva and semen. Infect Immun, 16 (3):928-933.

Alter, M. J. (1993). Community acquired viral hepatitis B and C in the United States. Gut, 34 (2 Suppl):S17-19.

Alter, M. J., M. S. Favero, and J. E. Maynard. (1986). Impact of infection control strategies on the incidence of dialysis-associated hepatitis in the United States. J Infect Dis, 153 (6):1149-1151.

Alvarado-Esquivel, C., E. Sablon, C. J. Conde-Gonzalez, L. Juarez-Figueroa, L. Ruiz-Maya, and S. Aguilar-Benavides. (2006). Molecular analysis of hepatitis B virus isolates in Mexico: predominant circulation of hepatitis B virus genotype H. World J Gastroenterol, 12 (40):6540-6545.

Angus, P., R. Vaughan, S. Xiong, H. Yang, W. Delaney, C. Gibbs, C. Brosgart, D. Colledge, R. Edwards, A. Ayres, A. Bartholomeusz, and S. Locarnini. (2003). Resistance to adefovir dipivoxil therapy associated with the selection of a novel mutation in the HBV polymerase. Gastroenterology, 125 (2):292-297.

Araujo, N. M., M. Branco-Vieira, A. C. Silva, J. H. Pilotto, B. Grinsztejn, A. J. de Almeida, C. Trepo, and S. A. Gomes. (2008). Occult hepatitis B virus infection in HIV-infected patients: Evaluation of biochemical, virological and molecular parameters. Hepatol Res, 38 (12):1194-1203.

Araujo, N. M., F. C. Mello, C. F. Yoshida, C. Niel, and S. A. Gomes. (2004). High proportion of subgroup A' (genotype A) among Brazilian isolates of Hepatitis B virus. Arch Virol, 149 (7):1383-1395.

Arauz-Ruiz, P., H. Norder, B. H. Robertson, and L. O. Magnius. (2002). Genotype H: a new Amerindian genotype of hepatitis B virus revealed in Central America. J Gen Virol, 83 (Pt 8):2059-2073.

Assad, S., and A. Francis. (1999). Over a decade of experience with a yeast recombinant hepatitis B vaccine. Vaccine, 18 (1-2):57-67.

Bayer, M. E., B. S. Blumberg, and B. Werner. (1968). Particles associated with Australia antigen in the sera of patients with leukaemia, Down's Syndrome and hepatitis. Nature, 218 (5146):1057-1059.

Beltrami, E. M., I. T. Williams, C. N. Shapiro, and M. E. Chamberland. (2000). Risk and management of blood-borne infections in health care workers. Clin Microbiol Rev, 13 (3):385-407.

Besisik, F., C. Karaca, F. Akyuz, S. Horosanli, D. Onel, S. Badur, M. S. Sever, A. Danalioglu, K. Demir, S. Kaymakoglu, Y. Cakaloglu, and A. Okten. (2003). Occult HBV 
infection and YMDD variants in hemodialysis patients with chronic HCV infection. J Hepatol, 38 (4):506-510.

Blumberg, B. S. (1997). Hepatitis B virus, the vaccine, and the control of primary cancer of the liver. Proc Natl Acad Sci U S A, 94 (14):7121-7125.

Blumberg, B. S., B. J. Gerstley, D. A. Hungerford, W. T. London, and A. I. Sutnick. (1967). A serum antigen (Australia antigen) in Down's syndrome, leukemia, and hepatitis. Ann Intern Med, 66 (5):924-931.

Boulaajaj, K., Y. Elomari, B. Elmaliki, B. Madkouri, D. Zaid, and N. Benchemsi. (2005). [Prevalence of hepatitis C, hepatitis B and HIV infection among haemodialysis patients in Ibn-Rochd university hospital, Casablanca]. Nephrol Ther, 1 (5):274-284.

Bowyer, S. M., L. van Staden, M. C. Kew, and J. G. Sim. (1997). A unique segment of the hepatitis B virus group A genotype identified in isolates from South Africa. J Gen Virol, 78 ( Pt 7):1719-1729.

Brechot, C., V. Thiers, D. Kremsdorf, B. Nalpas, S. Pol, and P. Paterlini-Brechot. (2001). Persistent hepatitis B virus infection in subjects without hepatitis B surface antigen: clinically significant or purely "occult"? Hepatology, 34 (1):194-203.

Busek, S. U., E. H. Baba, H. A. Tavares Filho, L. Pimenta, A. Salomao, R. Correa-Oliveira, and G. C. Oliveira. (2002). Hepatitis C and hepatitis B virus infection in different hemodialysis units in Belo Horizonte, Minas Gerais, Brazil. Mem Inst Oswaldo Cruz, 97 (6):775-778.

Canero-Velasco, M. C., J. E. Mutti, J. E. Gonzalez, A. Alonso, L. Otegui, M. Adragna, M. Antonuccio, M. Laso, M. Montenegro, L. Repetto, M. Brandi, J. Canepa, and E. Baimberg. (1998). [HCV and HBV prevalence in hemodialyzed pediatric patients. Multicenter study]. Acta Gastroenterol Latinoam, 28 (3):265-268.

Carman, W. F., F. J. Van Deursen, L. T. Mimms, D. Hardie, R. Coppola, R. Decker, and R. Sanders. (1997). The prevalence of surface antigen variants of hepatitis B virus in Papua New Guinea, South Africa, and Sardinia. Hepatology, 26 (6):1658-1666.

Castro-Figueiredo, J. F., M. Moyses-Neto, U. A. Gomes, A. Spalini-Ferraz, M. E. NardinBatista, A. M. Coimbra-Gaspar, and C. F. Tachibana-Yoshida. (1986). Hepatitis B virus infection in hemodialysis units: clinical features, epidemiological markers and general control measures. Braz J Med Biol Res, 19 (6):735-742.

CDC. (1991). Hepatitis B virus: a comprehensive strategy for eliminating transmission in the United States through universal childhood vaccination. Recommendations of the Immunization Practices Advisory Committee (ACIP). MMWR Recomm Rep, 40 (RR13):1-25.

CDC. (2001). Recommendations for preventing transmission of infections among chronic hemodialysis patients. MMWR Recomm Rep, 50 (RR-5):1-43.

CDC. Hepatitis B FAQs for Health Professionals 2011 [cited. Available from <http://www.cdc.gov/hepatitis/HBV/HBVfaq.htm>

Chan, H. L., A. Y. Hui, M. L. Wong, A. M. Tse, L. C. Hung, V. W. Wong, and J. J. Sung. (2004). Genotype C hepatitis B virus infection is associated with an increased risk of hepatocellular carcinoma. Gut, 53 (10):1494-1498.

Chattopadhyay, S., S. Rao, B. C. Das, N. P. Singh, and P. Kar. (2005). Prevalence of transfusion-transmitted virus infection in patients on maintenance hemodialysis from New Delhi, India. Hemodial Int, 9 (4):362-366. 
Chaudhuri, V., R. Tayal, B. Nayak, S. K. Acharya, and S. K. Panda. (2004). Occult hepatitis B virus infection in chronic liver disease: full-length genome and analysis of mutant surface promoter. Gastroenterology, 127 (5):1356-1371.

Chemin, I., and C. Trepo. (2005). Clinical impact of occult HBV infections. J Clin Virol, 34 Suppl 1:S15-21.

Chen, C. H., H. L. Eng, C. M. Lee, F. Y. Kuo, S. N. Lu, C. M. Huang, H. D. Tung, C. L. Chen, and C. S. Changchien. (2004). Correlations between hepatitis B virus genotype and cirrhotic or non-cirrhotic hepatoma. Hepatogastroenterology, 51 (56):552-555.

Chen, D. S. (2009). Hepatitis B vaccination: The key towards elimination and eradication of hepatitis B. J Hepatol, 50 (4):805-816.

Chu, C. J., and A. S. Lok. (2002). Clinical significance of hepatitis B virus genotypes. Hepatology, 35 (5):1274-1276.

Colonno, R. J., R. Rose, C. J. Baldick, S. Levine, K. Pokornowski, C. F. Yu, A. Walsh, J. Fang, M. Hsu, C. Mazzucco, B. Eggers, S. Zhang, M. Plym, K. Klesczewski, and D. J. Tenney. (2006). Entecavir resistance is rare in nucleoside naive patients with hepatitis B. Hepatology, 44 (6):1656-1665.

Conjeevaram, H. S., and A. S. Lok. (2001). Occult hepatitis B virus infection: a hidden menace? Hepatology, 34 (1):204-206.

Coursaget, P., P. Le Cann, D. Leboulleux, M. T. Diop, O. Bao, and A. M. Coll. (1991). Detection of hepatitis B virus DNA by polymerase chain reaction in HBsAg negative Senegalese patients suffering from cirrhosis or primary liver cancer. FEMS Microbiol Lett, 67 (1):35-38.

Covic, A., L. Iancu, C. Apetrei, D. Scripcaru, C. Volovat, I. Mititiuc, and M. Covic. (1999). Hepatitis virus infection in haemodialysis patients from Moldavia. Nephrol Dial Transplant, 14 (1):40-45.

Dai, C. Y., M. L. Yu, W. L. Chuang, Z. Y. Lin, S. C. Chen, M. Y. Hsieh, L. Y. Wang, J. F. Tsai, and W. Y. Chang. (2001). Influence of hepatitis $C$ virus on the profiles of patients with chronic hepatitis B virus infection. J Gastroenterol Hepatol, 16 (6):636-640.

Dane, D. S., C. H. Cameron, and M. Briggs. (1970). Virus-like particles in serum of patients with Australia-antigen-associated hepatitis. Lancet, 1 (7649):695-698.

Davison, F., G. J. Alexander, R. Trowbridge, E. A. Fagan, and R. Williams. (1987). Detection of hepatitis B virus DNA in spermatozoa, urine, saliva and leucocytes, of chronic HBsAg carriers. A lack of relationship with serum markers of replication. J Hepatol, 4 (1):37-44.

De Castro, L., N. M. Araujo, R. R. Sabino, F. Alvarenga, C. F. Yoshida, and S. A. Gomes. (2000). Nosocomial spread of hepatitis B virus in two hemodialysis units, investigated by restriction fragment length polymorphism analysis. Eur J Clin Microbiol Infect Dis, 19 (7):531-537.

de Franchis, R., A. Hadengue, G. Lau, D. Lavanchy, A. Lok, N. McIntyre, A. Mele, G. Paumgartner, A. Pietrangelo, J. Rodes, W. Rosenberg, and D. Valla. (2003). EASL International Consensus Conference on Hepatitis B. 13-14 September, 2002 Geneva, Switzerland. Consensus statement (long version). J Hepatol, 39 Suppl 1:S3-25.

Delaney, W. E. t., H. Yang, C. E. Westland, K. Das, E. Arnold, C. S. Gibbs, M. D. Miller, and S. Xiong. (2003). The hepatitis B virus polymerase mutation rtV173L is selected during lamivudine therapy and enhances viral replication in vitro. J Virol, 77 (21):11833-11841. 
Dienstag, J. L. (2008). Hepatitis B virus infection. N Engl J Med, 359 (14):1486-1500.

Fabrizi, F., P. Messa, and P. Martin. (2008). Hepatitis B virus infection and the dialysis patient. Semin Dial, 21 (5):440-446.

Fabrizi, F., P. G. Messa, G. Lunghi, F. Aucella, S. Bisegna, S. Mangano, M. Villa, F. Barbisoni, E. Rusconi, and P. Martin. (2005). Occult hepatitis B virus infection in dialysis patients: a multicentre survey. Aliment Pharmacol Ther, 21 (11):1341-1347.

Fattovich, G., G. Giustina, S. Favarato, and A. Ruol. (1996). A survey of adverse events in 11,241 patients with chronic viral hepatitis treated with alfa interferon. J Hepatol, 24 (1):38-47.

Finelli, L., J. T. Miller, J. I. Tokars, M. J. Alter, and M. J. Arduino. (2005). National surveillance of dialysis-associated diseases in the United States, 2002. Semin Dial, 18 (1):52-61.

Fisker, N., C. Pedersen, M. Lange, N. T. Nguyen, K. T. Nguyen, J. Georgsen, and P. B. Christensen. (2004). Molecular epidemiology of hepatitis B virus infections in Denmark. J Clin Virol, 31 (1):46-52.

Ganem, D., and H. E. Varmus. (1987). The molecular biology of the hepatitis B viruses. Annu Rev Biochem, 56:651-693.

Gomes, S. A., C. F. Yoshida, and C. Niel. (1996). Detection of hepatitis B virus DNA in hepatitis B surface antigen-negative serum by polymerase chain reaction: evaluation of different primer pairs and conditions. Acta Virol, 40 (3):133-138.

Goral, V., H. Ozkul, S. Tekes, D. Sit, and A. K. Kadiroglu. (2006). Prevalence of occult HBV infection in haemodialysis patients with chronic HCV. World J Gastroenterol, 12 (21):3420-3424.

Gutierrez, C., M. Devesa, C. L. Loureiro, G. Leon, F. Liprandi, and F. H. Pujol. (2004). Molecular and serological evaluation of surface antigen negative hepatitis B virus infection in blood donors from Venezuela. J Med Virol, 73 (2):200-207.

Ho, D. D., T. Moudgil, and M. Alam. (1989). Quantitation of human immunodeficiency virus type 1 in the blood of infected persons. N Engl J Med, 321 (24):1621-1625.

Hollinger, F. 1991. Hepatitis B virus. In Viral Hepatitis. New York: Raven Press 1-37

Hollinger, F. B., and T. J. Liang, eds. 2001. Hepatitis B Virus. Edited by D. M. Knipe and P. M. Howley. 4 ed. Philadelphia: Lippincott Williams \& Wilkins.

$\mathrm{Hu}, \mathrm{K}$. Q. (2002). Occult hepatitis B virus infection and its clinical implications. J Viral Hepat, 9 (4):243-257.

Huy, T. T., H. Ushijima, T. Sata, and K. Abe. (2006). Genomic characterization of HBV genotype $\mathrm{F}$ in Bolivia: genotype $\mathrm{F}$ subgenotypes correlate with geographic distribution and T(1858) variant. Arch Virol, 151 (3):589-597.

Inoue, K., O. Ogawa, M. Yamada, T. Watanabe, H. Okamoto, and M. Yoshiba. (2006). Possible association of vigorous hepatitis $B$ virus replication with the development of fulminant hepatitis. J Gastroenterol, 41 (4):383-387.

Jeantet, D., I. Chemin, B. Mandrand, A. Tran, F. Zoulim, P. Merle, C. Trepo, and A. Kay. (2004). Cloning and expression of surface antigens from occult chronic hepatitis B virus infections and their recognition by commercial detection assays. J Med Virol, 73 (4):508-515.

Jeantet, D., I. Chemin, B. Mandrand, F. Zoulim, C. Trepo, and A. Kay. (2002). Characterization of two hepatitis B virus populations isolated from a hepatitis B surface antigen-negative patient. Hepatology, 35 (5):1215-1224. 
Kanbay, M., G. Gur, A. Akcay, H. Selcuk, U. Yilmaz, H. Arslan, S. Boyacioglu, and F. N. Ozdemir. (2006). Is hepatitis C virus positivity a contributing factor to occult hepatitis B virus infection in hemodialysis patients? Dig Dis Sci, 51 (11):1962-1966.

Kao, J. H. (2002). Clinical relevance of hepatitis B viral genotypes: a case of deja vu? J Gastroenterol Hepatol, 17 (2):113-115.

Karayiannis, P. (2004). Current therapies for chronic hepatitis B virus infection. Expert Rev Anti Infect Ther, 2 (5):745-760.

Kondili, L. A., D. Genovese, C. Argentini, P. Chionne, P. Toscani, R. Fabro, R. Cocconi, and M. Rapicetta. (2006). Nosocomial transmission in simultaneous outbreaks of hepatitis C and B virus infections in a hemodialysis center. Eur J Clin Microbiol Infect Dis, 25 (8):527-531.

Kramvis, A., K. Arakawa, M. C. Yu, R. Nogueira, D. O. Stram, and M. C. Kew. (2008). Relationship of serological subtype, basic core promoter and precore mutations to genotypes/subgenotypes of hepatitis B virus. J Med Virol, 80 (1):27-46.

Kramvis, A., and M. C. Kew. (2005). Relationship of genotypes of hepatitis B virus to mutations, disease progression and response to antiviral therapy. J Viral Hepat, 12 (5):456-464.

Kramvis, A., L. Weitzmann, W. K. Owiredu, and M. C. Kew. (2002). Analysis of the complete genome of subgroup A' hepatitis B virus isolates from South Africa. J Gen Virol, 83 (Pt 4):835-839.

Krugman, S. (1989). Hepatitis B: historical aspects. Am J Infect Control, 17 (3):165-167.

Lewis-Ximenez, L. L., J. M. Oliveira, L. A. Mercadante, L. De Castro, W. Santa Catharina, S. Stuver, and C. F. Yoshida. (2001). Serological and vaccination profile of hemodialysis patients during an outbreak of hepatitis B virus infection. Nephron, 87 (1):19-26.

Lindh, M., C. Hannoun, A. P. Dhillon, G. Norkrans, and P. Horal. (1999). Core promoter mutations and genotypes in relation to viral replication and liver damage in East Asian hepatitis B virus carriers. J Infect Dis, 179 (4):775-782.

Liu, C. J., and J. H. Kao. (2008). Genetic variability of hepatitis B virus and response to antiviral therapy. Antivir Ther, 13 (5):613-624.

Locarnini, S. (2008). Primary resistance, multidrug resistance, and cross-resistance pathways in HBV as a consequence of treatment failure. Hepatol Int, 2 (2):147-151.

Locarnini, S. A. (1998). Hepatitis B virus surface antigen and polymerase gene variants: potential virological and clinical significance. Hepatology, 27 (1):294-297.

Lurman, A. (1885). Eine icterusepidemic. Berl Klin Wochenschr, 22:20-23.

Lusida, M. I., V. E. Nugrahaputra, Soetjipto, R. Handajani, M. Nagano-Fujii, M. Sasayama, T. Utsumi, and H. Hotta. (2008). Novel subgenotypes of hepatitis B virus genotypes C and D in Papua, Indonesia. J Clin Microbiol, 46 (7):2160-2166.

Lusida, M. I., Surayah, H. Sakugawa, M. Nagano-Fujii, Soetjipto, Mulyanto, R. Handajani, Boediwarsono, P. B. Setiawan, C. A. Nidom, S. Ohgimoto, and H. Hotta. (2003). Genotype and subtype analyses of hepatitis B virus (HBV) and possible coinfection of $\mathrm{HBV}$ and hepatitis $\mathrm{C}$ virus (HCV) or hepatitis D virus (HDV) in blood donors, patients with chronic liver disease and patients on hemodialysis in Surabaya, Indonesia. Microbiol Immunol, 47 (12):969-975.

Margolis, H. S., M. J. Alter, and S. C. Hadler. (1991). Hepatitis B: evolving epidemiology and implications for control. Semin Liver Dis, 11 (2):84-92. 
Mayerat, C., A. Mantegani, and P. C. Frei. (1999). Does hepatitis B virus (HBV) genotype influence the clinical outcome of HBV infection? J Viral Hepat, 6 (4):299-304.

McIntyre, N. (1990). Clinical presentation of acute viral hepatitis. Br Med Bull, 46 (2):533-547.

McMahon, B. J. (2009). The influence of hepatitis B virus genotype and subgenotype on the natural history of chronic hepatitis B. Hepatol Int, 3 (2):334-342.

Meldal, B. H., N. M. Moula, I. H. Barnes, K. Boukef, and J. P. Allain. (2009). A novel hepatitis B virus subgenotype, D7, in Tunisian blood donors. J Gen Virol, 90 (Pt 7):1622-1628.

Melegari, M., P. P. Scaglioni, and J. R. Wands. (1998). Hepatitis B virus mutants associated with $3 \mathrm{TC}$ and famciclovir administration are replication defective. Hepatology, 27 (2):628-633.

Mello, F. C., N. Martel, S. A. Gomes, and N. M. Araujo. (2011). Expression of Hepatitis B Virus Surface Antigen Containing Y100C Variant Frequently Detected in Occult HBV Infection. Hepat Res Treat, 2011:695859.

Mello, F. C., F. J. Souto, L. C. Nabuco, C. A. Villela-Nogueira, H. S. Coelho, H. C. Franz, J. C. Saraiva, H. A. Virgolino, A. R. Motta-Castro, M. M. Melo, R. M. Martins, and S. A. Gomes. (2007). Hepatitis B virus genotypes circulating in Brazil: molecular characterization of genotype $\mathrm{F}$ isolates. BMC Microbiol, 7:103.

Minuk, G. Y., D. F. Sun, R. Greenberg, M. Zhang, K. Hawkins, J. Uhanova, A. Gutkin, K. Bernstein, A. Giulivi, and C. Osiowy. (2004). Occult hepatitis B virus infection in a North American adult hemodialysis patient population. Hepatology, 40 (5):10721077.

Motta-Castro, A. R., R. M. Martins, N. M. Araujo, C. Niel, G. B. Facholi, B. V. Lago, F. C. Mello, and S. A. Gomes. (2008). Molecular epidemiology of hepatitis B virus in an isolated Afro-Brazilian community. Arch Virol, 153 (12):2197-2205.

Motta, J. S., F. C. Mello, B. V. Lago, R. M. Perez, S. A. Gomes, and F. F. Figueiredo. (2010). Occult hepatitis B virus infection and lamivudine-resistant mutations in isolates from renal patients undergoing hemodialysis. J Gastroenterol Hepatol, 25 (1):101-106.

Mulyanto, S. N. Depamede, K. Surayah, F. Tsuda, K. Ichiyama, M. Takahashi, and H. Okamoto. (2009). A nationwide molecular epidemiological study on hepatitis B virus in Indonesia: identification of two novel subgenotypes, B8 and C7. Arch Virol, 154 (7):1047-1059.

Norder, H., A. M. Courouce, P. Coursaget, J. M. Echevarria, S. D. Lee, I. K. Mushahwar, B. H. Robertson, S. Locarnini, and L. O. Magnius. (2004). Genetic diversity of hepatitis B virus strains derived worldwide: genotypes, subgenotypes, and HBsAg subtypes. Intervirology, 47 (6):289-309.

Norder, H., A. M. Courouce, and L. O. Magnius. (1994). Complete genomes, phylogenetic relatedness, and structural proteins of six strains of the hepatitis B virus, four of which represent two new genotypes. Virology, 198 (2):489-503.

Nurainy, N., D. H. Muljono, H. Sudoyo, and S. Marzuki. (2008). Genetic study of hepatitis B virus in Indonesia reveals a new subgenotype of genotype B in east Nusa Tenggara. Arch Virol, 153 (6):1057-1065.

Okochi, K., and S. Murakami. (1968). Observations on Australia antigen in Japanese. Vox Sang, 15 (5):374-385.

Olinger, C. M., P. Jutavijittum, J. M. Hubschen, A. Yousukh, B. Samountry, T. Thammavong, K. Toriyama, and C. P. Muller. (2008). Possible new hepatitis B virus genotype, southeast Asia. Emerg Infect Dis, 14 (11):1777-1780. 
Oliveira, M. L., F. I. Bastos, P. R. Telles, C. F. Yoshida, H. G. Schatzmayr, U. Paetzold, G. Pauli, and E. Schreier. (1999). Prevalence and risk factors for HBV, HCV and HDV infections among injecting drug users from Rio de Janeiro, Brazil. Braz J Med Biol Res, 32 (9):1107-1114.

Ono, S. K., N. Kato, Y. Shiratori, J. Kato, T. Goto, R. F. Schinazi, F. J. Carrilho, and M. Omata. (2001). The polymerase L528M mutation cooperates with nucleotide binding-site mutations, increasing hepatitis B virus replication and drug resistance. J Clin Invest, 107 (4):449-455.

Ozasa, A., Y. Tanaka, E. Orito, M. Sugiyama, J. H. Kang, S. Hige, T. Kuramitsu, K. Suzuki, E. Tanaka, S. Okada, H. Tokita, Y. Asahina, K. Inoue, S. Kakumu, T. Okanoue, Y. Murawaki, K. Hino, M. Onji, H. Yatsuhashi, H. Sakugawa, Y. Miyakawa, R. Ueda, and M. Mizokami. (2006). Influence of genotypes and precore mutations on fulminant or chronic outcome of acute hepatitis B virus infection. Hepatology, 44 (2):326-334.

Panessa, C., W. D. Hill, E. Giles, A. Yu, S. Harvard, G. Butt, A. Andonov, M. Krajden, and C. Osiowy. (2009). Genotype D amongst injection drug users with acute hepatitis B virus infection in British Columbia. J Viral Hepat, 16 (1):64-73.

Paniagua, R., A. Villasis-Keever, C. Prado-Uribe Mdel, M. D. Ventura-Garcia, G. AlcantaraOrtega, S. R. Ponce de Leon, N. Cure-Bolt, and S. Rangel-Frausto. (2010). Elevated prevalence of hepatitis B in Mexican hemodialysis patients. A multicentric survey. Arch Med Res, 41 (4):251-254.

Perrillo, R. P., C. R. Campbell, S. Strang, C. J. Bodicky, and D. J. Costigan. (1984). Immune globulin and hepatitis B immune globulin. Prophylactic measures for intimate contacts exposed to acute type B hepatitis. Arch Intern Med, 144 (1):81-85.

Piot, P., C. Goilav, and E. Kegels. (1990). Hepatitis B: transmission by sexual contact and needle sharing. Vaccine, 8 Suppl:S37-40; discussion S41-33.

Pourkarim, M. R., P. Lemey, S. Amini-Bavil-Olyaee, P. Maes, and M. Van Ranst. (2010). Novel hepatitis B virus subgenotype A6 in African-Belgian patients. J Clin Virol, 47 (1):93-96.

Prince, A. M. (1968). An antigen detected in the blood during the incubation period of serum hepatitis. Proc Natl Acad Sci U S A, 60 (3):814-821.

Raimondo, G., T. Pollicino, I. Cacciola, and G. Squadrito. (2007). Occult hepatitis B virus infection. J Hepatol, 46 (1):160-170.

Ramalingam, S., T. Leung, H. Cairns, P. Sibley, M. Smith, S. Ijaz, R. Tedder, and M. Zuckerman. (2007). Transmission of hepatitis B virus (genotype E) in a haemodialysis unit. J Clin Virol, 40 (2):105-109.

Roll, M., H. Norder, L. O. Magnius, L. Grillner, and V. Lindgren. (1995). Nosocomial spread of hepatitis $B$ virus (HBV) in a haemodialysis unit confirmed by HBV DNA sequencing. J Hosp Infect, 30 (1):57-63.

RosenheimAdvisoryGroup. 1972. Hepatitis and the Treatment of Chronic Renal Failure, edited by D. o. H. a. S. Security. London.

Sakamoto, T., Y. Tanaka, E. Orito, J. Co, J. Clavio, F. Sugauchi, K. Ito, A. Ozasa, A. Quino, R. Ueda, J. Sollano, and M. Mizokami. (2006). Novel subtypes (subgenotypes) of hepatitis $\mathrm{B}$ virus genotypes $\mathrm{B}$ and $\mathrm{C}$ among chronic liver disease patients in the Philippines. J Gen Virol, 87 (Pt 7):1873-1882.

Schaefer, S. (2005). Hepatitis B virus: significance of genotypes. J Viral Hepat, 12 (2):111-124. 
Siagris, D., M. Christofidou, K. Triga, N. Pagoni, G. J. Theocharis, D. Goumenos, A. Lekkou, K. Thomopoulos, A. C. Tsamandas, J. Vlachojannis, and C. Labropoulou-Karatza. (2006). Occult hepatitis B virus infection in hemodialysis patients with chronic HCV infection. J Nephrol, 19 (3):327-333.

Simonsen, L., A. Kane, J. Lloyd, M. Zaffran, and M. Kane. (1999). Unsafe injections in the developing world and transmission of bloodborne pathogens: a review. Bull World Health Organ, 77 (10):789-800.

Sjogren, M. H. (1994). Serologic diagnosis of viral hepatitis. Gastroenterol Clin North Am, 23 (3):457-477.

Stuyver, L., S. De Gendt, C. Van Geyt, F. Zoulim, M. Fried, R. F. Schinazi, and R. Rossau. (2000). A new genotype of hepatitis B virus: complete genome and phylogenetic relatedness. J Gen Virol, 81 (Pt 1):67-74.

Sugiyama, M., Y. Tanaka, T. Kato, E. Orito, K. Ito, S. K. Acharya, R. G. Gish, A. Kramvis, T. Shimada, N. Izumi, M. Kaito, Y. Miyakawa, and M. Mizokami. (2006). Influence of hepatitis B virus genotypes on the intra- and extracellular expression of viral DNA and antigens. Hepatology, 44 (4):915-924.

Swenson, P. D., C. Van Geyt, E. R. Alexander, H. Hagan, J. M. Freitag-Koontz, S. Wilson, H. Norder, L. O. Magnius, and L. Stuyver. (2001). Hepatitis B virus genotypes and HBsAg subtypes in refugees and injection drug users in the United States determined by LiPA and monoclonal EIA. J Med Virol, 64 (3):305-311.

Tatematsu, K., Y. Tanaka, F. Kurbanov, F. Sugauchi, S. Mano, T. Maeshiro, T. Nakayoshi, M. Wakuta, Y. Miyakawa, and M. Mizokami. (2009). A genetic variant of hepatitis B virus divergent from known human and ape genotypes isolated from a Japanese patient and provisionally assigned to new genotype J. J Virol, 83 (20):10538-10547.

Te, H. S., and D. M. Jensen. (2010). Epidemiology of hepatitis B and C viruses: a global overview. Clin Liver Dis, 14 (1):1-21, vii.

Teles, S. A., R. M. Martins, S. A. Gomes, A. M. Gaspar, N. M. Araujo, K. P. Souza, M. A. Carneiro, and C. F. Yoshida. (2002). Hepatitis B virus transmission in Brazilian hemodialysis units: serological and molecular follow-up. J Med Virol, 68 (1):41-49.

Tokars, J. I., M. Frank, M. J. Alter, and M. J. Arduino. (2002). National surveillance of dialysis-associated diseases in the United States, 2000. Semin Dial, 15 (3):162-171.

Torbenson, M., and D. L. Thomas. (2002). Occult hepatitis B. Lancet Infect Dis, 2 (8):479-486.

Torresi, J., L. Earnest-Silveira, G. Deliyannis, K. Edgtton, H. Zhuang, S. A. Locarnini, J. Fyfe, T. Sozzi, and D. C. Jackson. (2002). Reduced antigenicity of the hepatitis B virus HBsAg protein arising as a consequence of sequence changes in the overlapping polymerase gene that are selected by lamivudine therapy. Virology, 293 (2):305-313.

Tran, T. T., T. N. Trinh, and K. Abe. (2008). New complex recombinant genotype of hepatitis B virus identified in Vietnam. J Virol, 82 (11):5657-5663.

Utsumi, T., M. I. Lusida, Y. Yano, V. E. Nugrahaputra, M. Amin, Juniastuti, Soetjipto, Y. Hayashi, and H. Hotta. (2009). Complete genome sequence and phylogenetic relatedness of hepatitis B virus isolates in Papua, Indonesia. J Clin Microbiol, 47 (6):1842-1847.

Villa, E., A. Grottola, P. Buttafoco, P. Trande, A. Merighi, N. Fratti, Y. Seium, G. Cioni, and F. Manenti. (1995). Evidence for hepatitis B virus infection in patients with chronic hepatitis C with and without serological markers of hepatitis B. Dig Dis Sci, 40 (1):8-13. 
Vladutiu, D. S., A. Cosa, A. Neamtu, D. State, M. Braila, M. Gherman, I. M. Patiu, and I. Dulau-Florea. (2000). Infections with hepatitis B and C viruses in patients on maintenance dialysis in Romania and in former communist countries: yellow spots on a blank map? J Viral Hepat, 7 (4):313-319.

Wang, Z., Y. Huang, S. Wen, B. Zhou, and J. Hou. (2007). Hepatitis B virus genotypes and subgenotypes in China. Hepatol Res, 37 (s1):S36-41.

WHO. Hepatitis B. World Health Organization Fact Sheet 2008 [cited. Available from http://www.who.int/mediacentre/factsheets/fs204/en/index.html.

Wiegand, J., D. Hasenclever, and H. L. Tillmann. (2008). Should treatment of hepatitis B depend on hepatitis B virus genotypes? A hypothesis generated from an explorative analysis of published evidence. Antivir Ther, 13 (2):211-220.

Wreghitt, T. G. (1999). Blood-borne virus infections in dialysis units--a review. Rev Med Virol, 9 (2):101-109.

Yamamoto, K., M. Horikita, F. Tsuda, K. Itoh, Y. Akahane, S. Yotsumoto, H. Okamoto, Y. Miyakawa, and M. Mayumi. (1994). Naturally occurring escape mutants of hepatitis $B$ virus with various mutations in the $S$ gene in carriers seropositive for antibody to hepatitis B surface antigen. J Virol, 68 (4):2671-2676.

Yang, H., X. Qi, A. Sabogal, M. Miller, S. Xiong, and W. E. t. Delaney. (2005). Crossresistance testing of next-generation nucleoside and nucleotide analogues against lamivudine-resistant HBV. Antivir Ther, 10 (5):625-633.

Zoulim, F., and S. Locarnini. (2009). Hepatitis B virus resistance to nucleos(t)ide analogues. Gastroenterology, 137 (5):1593-1608 e1591-1592. 


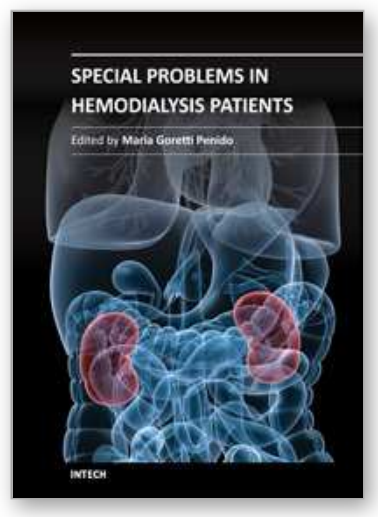

\author{
Special Problems in Hemodialysis Patients \\ Edited by Prof. Maria Goretti Penido
}

ISBN 978-953-307-396-5

Hard cover, 192 pages

Publisher InTech

Published online 14, November, 2011

Published in print edition November, 2011

This book provides an overview of special cases in hemodialysis patients. Authors have contributed their most interesting findings in dealing with patients suffering of other diseases simultaneously, such as diabetes, cardiovascular disease and other health problems. Each chapter has been thoroughly revised and updated so the readers are acquainted with the latest data and observations in these complex cases, where several aspects are to be considered. The book is comprehensive and not limited to a partial discussion of hemodialysis. To accomplish this we are pleased to have been able to summarize state of the art knowledge in each chapter of the book.

\title{
How to reference
}

In order to correctly reference this scholarly work, feel free to copy and paste the following:

Selma A. Gomes, Francisco C. Mello and Natalia M. Araujo (2011). Hepatitis B Virus (HBV) Variants in Hemodialysis Patients, Special Problems in Hemodialysis Patients, Prof. Maria Goretti Penido (Ed.), ISBN: 978953-307-396-5, InTech, Available from: http://www.intechopen.com/books/special-problems-in-hemodialysispatients/hepatitis-b-virus-hbv-variants-in-hemodialysis-patients

\section{INTECH}

open science | open minds

\section{InTech Europe}

University Campus STeP Ri

Slavka Krautzeka 83/A

51000 Rijeka, Croatia

Phone: +385 (51) 770447

Fax: +385 (51) 686166

www.intechopen.com

\section{InTech China}

Unit 405, Office Block, Hotel Equatorial Shanghai

No.65, Yan An Road (West), Shanghai, 200040, China

中国上海市延安西路65号上海国际贵都大饭店办公楼405单元

Phone: +86-21-62489820

Fax: +86-21-62489821 
(C) 2011 The Author(s). Licensee IntechOpen. This is an open access article distributed under the terms of the Creative Commons Attribution 3.0 License, which permits unrestricted use, distribution, and reproduction in any medium, provided the original work is properly cited. 